\title{
STUDY OF INFLUENCE OF CALCIUM CONTENT IN MILK ON QUALITY INDICATORS OF COTTAGE CHEESE
}

\author{
Nataliya Grynchenko \\ Department of Meat Processing Technologies \\ Kharkiv State University of Food Technologies and Trade \\ 333 Klochkivska str., Kharkiv, Ukraine, 61051 \\ tatagrin1201@gmail.com \\ Daria Tyutyukova \\ Department of Meat Processing Technologies \\ Kharkiv State University of Food Technologies and Trade \\ 333 Klochkivska str., Kharkiv, Ukraine, 61051 \\ tutukova.d.o.hduht@gmail.com \\ Pavlo Pyvovarov \\ Department of Meat Processing Technologies \\ Kharkiv State University of Food Technologies and Trade \\ 333 Klochkivska str., Kharkiv, Ukraine, 61051 \\ pcub@ukr.net
}

\begin{abstract}
The analysis was realized, and the dependence between the calcium content and organoleptic and functional-technological properties of milk as a raw material for producing sour milk cheese was determined. It was demonstrated, that alongside with other factors, the important role in milk clotting belongs to calcium, which role is in binding of free $\mathrm{OH}$-groups of phosphoric acid of casein micelles. As a result of the aforesaid, their negative charge and colloid stability decrease with further hydrophilicity decrease with further aggregation of casein molecules. It was established, that the excessive content of calcium in milk is negative that is manifested in formation of the dry and brittle consistence of sour milk cheese. There was offered the way of calcium content regulation in milk by its decalcification using the natural sorbent of sodium alginate. Regulation of the milk salt system, especially, the calcium content as an initial raw material for producing sour milk cheese by the change of the content and condition of calcium allowed to correct parameters of the process of sour milk cheese making and its functional-technological properties, especially, moisture-keeping ability, form stability and other. It was established, that the decrease of the calcium content in milk provides getting sour milk cheese with the soft, easily smearing consistence, without whey separation. The obtained data on the characteristic of organoleptic indicators fully correlate with studies of the microstructure and dispersity of sour milk cheese. It was determined, that milk decalcification results in raising dispersity of sour milk cheese at the synchronous increase of the percent content of protein particles with minimal size characteristics in the system. It was elucidated, that the microstructure of studied samples consists of protein grains of the same form, evenly distributed by the whole volume. Based on the obtained experimental data, there were corrected parameters of the technological process of sour milk cheese production. There were elaborated ways of formation of the culinary products assortment on the base of sour milk cheese, produced of decalcified milk.
\end{abstract}

Keywords: skim milk, regulated content of calcium, decalcification, sodium alginate, sour milk cheese, casein micelles, moisture-keeping ability, textural characteristics.

\section{Introduction}

Coagulation of milk proteins (mainly casein) is the one of important physical-chemical processes that is in the base of industrial technologies of sour milk cheese, cheese desserts, sour milk beverages and is determined by functional-technological properties of a raw material. Technological properties of milk are considered in the modern literature as [1, 2], which realization provides getting milk products with given consumption properties. The technological process of sour milk cheese production provides using the raw material with the high ability to the acid or rennet clotting, conditioned by casein properties to coagulate under conditions of the medium $\mathrm{pH}$ decrease $[3,4]$. 
Calcium plays the important role in this process. Its quantitative content in the raw material considerably influences the process of a protein clot formation in the process of milk pickling, and also the quality of sour milk cheese that is a reflection of its organoleptic, structural-mechanical and functional-technological properties [5-7].

Fundamentalization of existent ideas about the role of calcium and regularity of milk proteins coagulation, understanding of the interconnection between the content, structure and functional-technological properties of casein allow to prognosticate a possibility of its structural modifications. Such modifications induce the increase of hydrophilicity, ability to dissociation, evenness of distribution of the surface charge and, correspondingly, correction of functional-technological properties $[8,9]$.

Modification of casein properties by milk decalcification using the natural ion-exchanger - sodium anginate considerably influences its technological properties [10,11]. So, the question of determining a dependence between the calcium content in milk and the quality of sour milk cheese, produced on its base, becomes urgent. Based on it, the aim of this research is the determination of the influence of the calcium content in milk on the quality of sour milk cheese, produced on its base. The established regularities between the aforesaid indicators allow to receive final products with stable quality indicators and to determine its proper use in technologies of culinary and confectionary products.

\section{Materials and Methods}

The subjects of the research were:

- skim milk, received by separating milk of the raw material zone of SE "SF "Kutuzyvka", NAAS of Ukraine;

- a complex-creator - sodium alginate (AlgNa) FD-157 (made by “Danisco", Denmark), allowed for use by the Central body of executive power in the sphere of health protection of Ukraine;

- skim milk with different content of calcium, achieved by sorption of ionized calcium by AlgNa solution;

- sour milk cheese, received from skim milk at the different content of calcium.

$\mathrm{AlgNa}$ solutions were received by dispersing of $\mathrm{AlgNa}$ batch in de-aired and demineralized drinking water at the temperature $18-20^{\circ} \mathrm{C}$ during (3-4) $\times 60 \mathrm{~s}$ with further keeping during $24 \times 60^{2} \mathrm{~s}$. These parameters are recommended by the firm-producer of $\mathrm{AlgNa}$, their observance allows to create all conditions for realizing functional-technological parameters of the used food additive.

Sorption of ionic calcium was realized by the drop introduction of $\mathrm{AlgNa}$ solution to skim cow milk with further keeping during 1 hour with formation of gel as sphere-like granules, eliminated by decantation.

Samples of sour milk cheese of skim milk (control) and decalcified milk were received by the traditional technology by the acid method of milk of one line [12]. Milk was pasteurized at the temperature $78-80{ }^{\circ} \mathrm{C}$ during $20-30 \mathrm{~s}$ and cooled to the temperature $32-34^{\circ} \mathrm{C}$. Prepared milk was added with pickling culture of the direct introduction and thermostated at the temperature $32-34{ }^{\circ} \mathrm{C}$ to $\mathrm{pH} 4,5-4,6$. The created clot was cut in bricks with the size $2 \times 2 \times 2 \mathrm{~cm}$ for better whey separation. For accelerating whey separation, the ready clot was thermally processed to the temperature $40-42{ }^{\circ} \mathrm{C}$ during (15-30).60 s. The boiled clot was separated from whey and self-pressed at the temperature $16-20{ }^{\circ} \mathrm{C}$. The received clot was cooled to the temperature $4-6{ }^{\circ} \mathrm{C}$.

The following research methods were used at experimental works.

\section{1. Methods of milk study}

The mass share of fat, protein, lactose, dry substance in milk with the different $\mathrm{Ca}^{2+}$ content was determined on the device BENTLEY SOMACOUNT-150 (Bentley Instruments Inc., USA) (Fig. 1).

The mass share of general mineral substances and mineral content of skim milk was determined on the roentgen-fluorescent analyzer ElvaX Light SDD (Elvatex, Ukraine) (Fig. 2).

The content of calcium in skim cow milk, decalcified cow milk was realized by the method of complex-sonometric titration. This method is based on the interaction between calcium and trilon $\mathrm{b}$ in the alkaline medium. This reaction results in the transfer of calcium from compounds 
with proteins and phosphorus in a solution. A residue of trilon $\mathrm{b}$ was titrated by the calcium chloride solution [13].

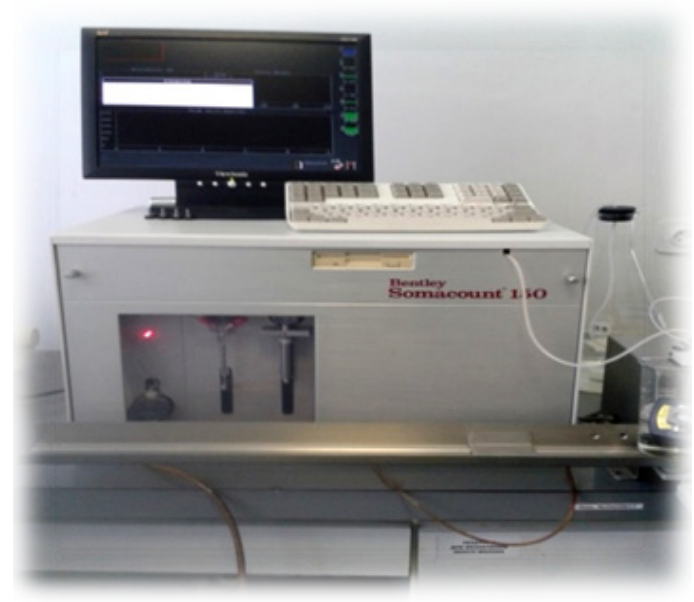

Fig. 1. Milk analyzer BENTLEY SOMACOUNT-150
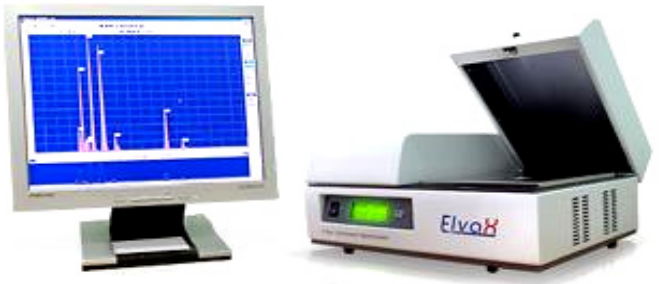

Fig. 2. Roentgen-fluorescent analyzer ElvaX Light SDD

The active acidity of skim milk was determined using pH-meter pH-150 MI (Measuring technique, Russia) with the electrode system for measuring $\mathrm{pH}$ (Fig. 3).

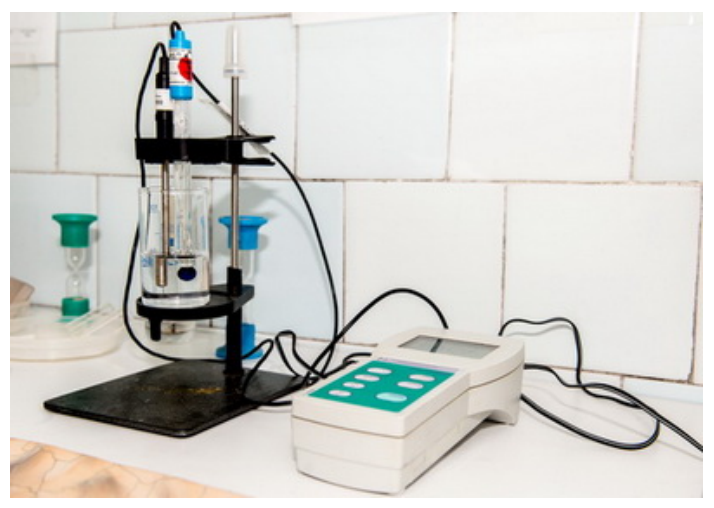

Fig. 3. pH-meter $\mathrm{pH}-150 \mathrm{MI}$

The titrated acidity of milk and sour-milk cheese - by titration of samples by $0,1 \mathrm{n}$ solution of sodium hydroxide. Titration was realized at presence of phenolphthalein up to faint pink coloration that doesn't disappear during $60 \mathrm{~s}$.

\section{2. Methods of studying acid clots and whey}

The moisture-extracting ability of protein clots (MEA) is determined by centrifuging at the division factor 1000. At the amount of separated whey, we judged about the clot's ability to moisture output. The results were expressed in the number of $\mathrm{ml}$ of whey, received of $10 \mathrm{~cm}^{3}$ of an acid clot. 
The mass share of protein and dry substance in whey was determined on the device BENTLEY SOMACOUNT-150 (Bentley Instruments Inc., USA).

\section{3. Methods of studying sour milk cheese}

The studies of the content of general protein in sour milk cheese at the different calcium content were realized by Kjeldahl method [14].

The moisture-keeping ability of sour milk cheese was determined by the gravimetric method. This method is based on determining the amount of water, separated from a product at light pressing, absorbed by filtering paper. Ash-free, slowly absorbing filters $\varnothing(9-11) \mathrm{mm}$, kept in the dessicator with chlorine calcium for establishing the constant moisture, were used in the work. A filter was placed on a glass plate with the size $11 \times 11 \times 0,5 \mathrm{~cm}$. The cheese batch $0,3 \mathrm{~g}$ was placed on a disk of polyethylene film with the diameter $40 \mathrm{~mm}$, weighed on analytic scales with exactness up to $0,5 \mathrm{mg}$ and transferred on a filter in such a way that the batch is under the polyethylene disk. The batch was covered by the glass plate of the same size and a load with the mass $0,5 \mathrm{~kg}$ was set on it. The content was pressed for (5-7) $60 \mathrm{~s}$. After that the filter with the batch was released from the load and plate. The cheese sample together with the polyethylene disk was taken of the filtering paper and weighed. The difference in the mass of the product with the disk before and after pressing demonstrates the mass of moisture, extracted from the sample. The moisture-keeping ability (MKA) was determined by formula (1).

$$
\mathrm{MKA}=100 \cdot \frac{\mathrm{a}-\mathrm{b}}{\mathrm{a}}
$$

where MKA - moisture-keeping ability of sour milk cheese, \%; a - amount of moisture in a cheese batch, $\mathrm{g} ; \mathrm{b}$ - amount of moisture, extracted from a cheese batch, $\mathrm{g}$.

The amount of moisture in a cheese batch was determined by formula (2):

$$
\mathrm{a}=\frac{300 \cdot \mathrm{B}_{\mathrm{sc}}}{100}
$$

where 300 - cheese batch, mg; $\mathrm{B}_{\mathrm{sc}}$ - mass share of moisture in sour milk cheese, $\%$.

The mass share of moisture in the studied systems was determined using the moisture analyzer "Kett Electric Laboratory", made by "Infrared Moisture Meter. Model F-IA" (Japan) (Fig. 4).

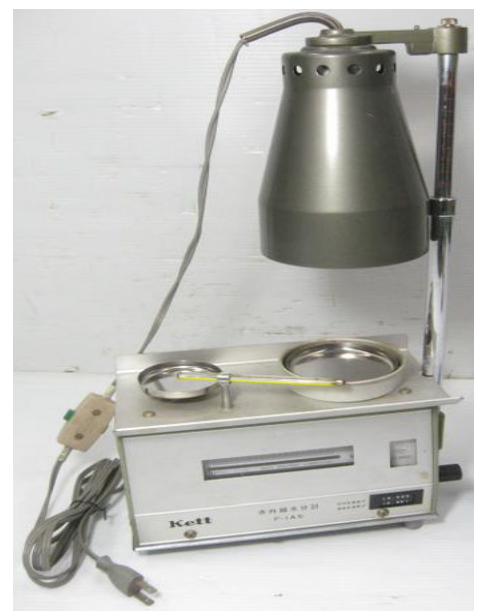

Fig. 4. Moisture analyzer "Kett Electric Laboratory", made by "Infrared Moisture Meter Model F-IA"

The action of this device is based on the thermogravimetric principle: moisture of the studied sample is determined by its mass decrease as a result of drying at heating. Infrared lamps are used as a heating element. 
The estimation of the sour milk cheese microstructure was realized using the light microscope with a photo header at 40-multiple magnification. For preparing samples, an average sample of sour milk cheese was rubbed in a mortar to the homogenous mass. Then 0,005 of the preparation were evenly brought by a loop on the slide glass, occasionally choosing vision fields at the whole preparation surface for obtaining objective, statistically reliable results and photographed.

The determination of dispersity of sour milk cheese was realized using the microscope with the digital photo camera ScopeTek DCM310 and personal computer with ScopePhoto software for processing obtained photos. A sample of the studied systems was photographed using the microscope and digital photo camera. The obtained photos were processed using ImageJ 1.47 software, calculating the number of particles and determining their diameter by formula (3):

$$
\mathrm{d}=2 \sqrt{\mathrm{S}} / \pi
$$

where $\mathrm{S}$ - particle area.

The optic density of sour milk cheese samples was measured on the concentrating photoelectronic colorimeter CPC-2 (Russia) (Fig. 5).

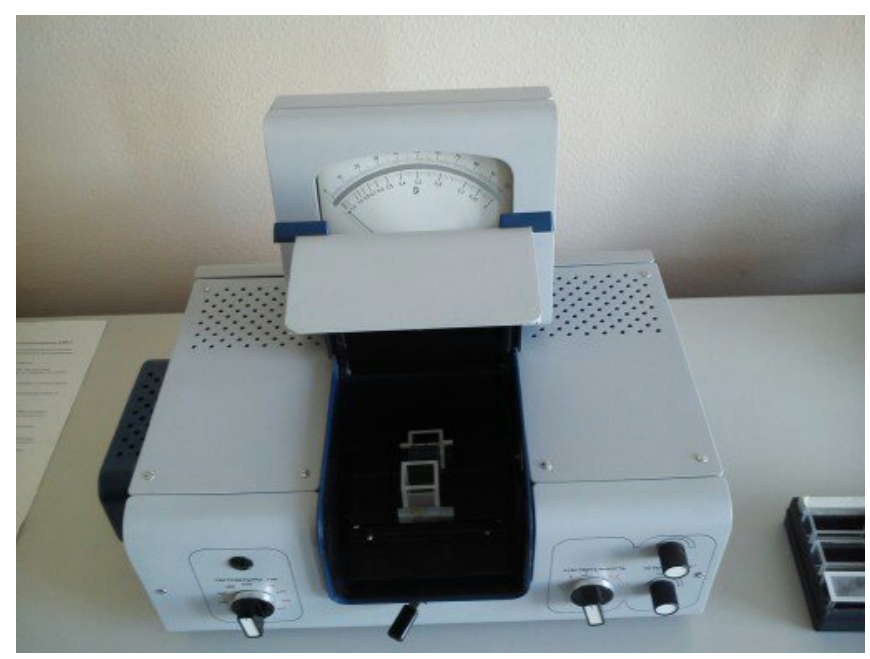

Fig. 5. Concentrative photoelectronic colorimeter CPC-2

Based on the obtained data, there was determined the sedimentation stability of selected samples. For preparing samples, a batch of sour milk cheese was rubbed in a mortar to the homogenous mass and mixed with distilled water in ratio sample:water 1:500. Dishes with the studied sample and distilled water were set in a dish-keeper. The wave length at measuring was $540 \mathrm{~nm}$.

The organoleptic estimation of samples was realized by the sensor analysis [15].

The experimental studies were realized in the following scientific-research laboratories:

- the laboratory of rheological studies of Kharkiv state university of food and trade (Ukraine);

- the laboratory of the estimation of forages and animal husbandry products, NAAS of Ukraine;

- the scientific-research laboratory of the chair of organic synthesis and nanotechnologies of Kharkiv national university "Kharkiv polytechnic institute" (Ukraine).

\section{Results}

The decrease of the calcium level in skim milk was realized by using the natural ion-exchanger - sodium alginate. It was determined, that the step-by-step introduction of sodium alginate in milk as a sequestrant allows to decrease the calcium level in it from $10 \%$ to $50 \%$. At that there is fixed the change of organoleptic properties of milk, especially its appearance that is manifested in glass-likeness and transparency increase.

The rational level of milk decalcification that is $20-25 \%$ was determined by the condition of a protein clot, whey, received after pressing a clot, and the sour milk cheese quality. It was 
established, that the dense clot with the satisfactory moisture-extracting ability forms in the rational interval of decalcification level. At that the mass share of soluble protein in whey is within legitimate values. The increase of the decalcification level up to $50 \%$ results in the increase of the soluble protein level in whey. It is conditioned by the transfer of low molecular casein fractions in the soluble condition. At the same time there is fixed the decrease of the output of sour milk cheese that is inadmissible from the point of view of the rational technological process realization.

There were studied organoleptic and physical-chemical indicators, output of sour milk cheese, received of skim milk at the different calcium content. The estimation of organoleptic properties was realized at the gustatory council with participation of 27 leading specialists of the university, included in the expert gustatory commission. The generalization on the research results allows to reveal the following regularities: the decrease of calcium content in skim milk essentially influences the consistence and appearance of sour milk cheese. At that the consistence of the control sample may be characterized as crumbly, brittle, grain-like with insufficient whey extraction. Samples, which calcium content was regulated by milk decalcification, are characterized by the homogenous, soft, plastic consistence. Whey in these samples is not separated, grain-likeness is absent. It must be also taken into account, that taste, smell and color of all samples are unchangeable, not depending of the amount of calcium, extracted from milk.

The obtained research data of organoleptic properties of sour milk cheese fully correlate with its indices of moisture-keeping ability, dispersity and sedimentation stability.

It was proved, that formation of easily smearing, plastic consistence is a result of the increased level of protein particles with the size characteristics $\leq 20 \mathrm{mcm}$. At the same time the increase of dispersity level results in formation of the stable hydrate tunic around protein particles. It is correspondingly reflected on the index of the moisture-keeping ability of sour milk cheese that regularly grows with increasing the milk decalcification level within rational values.

Thus, the regulation of calcium content in milk as an initial raw material for producing sour milk cheese by its decalcification allows to correct parameters of the technological process of sour milk cheese making. The result of such modification is also the increase of technological properties of sour milk cheese, especially, its moisture-keeping ability, form stability, texture change that is important from the point of view of its use in the technology of the wide assortment of culinary products (Fig. 6).

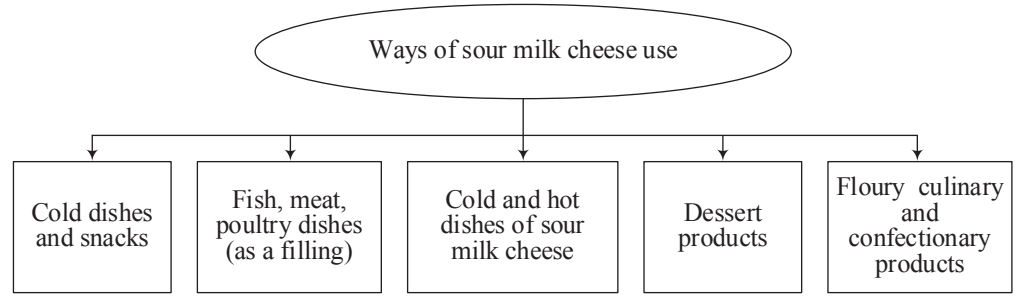

Fig. 6. Ways of formation of the assortment of culinary products based on sour milk cheese, made from decalcified milk

From the practical point of view, this mechanism of the calcium content regulation in milk allows to receive sour milk cheese with the high dispersity, moisture-keeping ability, homogenous structure and to increase the output of products that is economically grounded. Thus, the applied aspect of the offered technological solutions realization is the increase of the resource potential of milk as a raw material, increase of the technological process effectiveness, elaboration of the wide assortment of competitive products with high consumption properties for different population layers.

\section{Conclusions}

Within the realized studies the expedience of casein micelles modification by milk decalcification by sodium alginate was proved. The offered method allows to decrease the calcium level in milk to the certain level that allows to produce sour milk cheese with the homogenous structure, easily 
smearing, plastic consistence, without whey separation. The further use of sour milk cheese with determined characteristics in the technologies of culinary and confectionary products allows to avoid such additional operations as rubbing, homogenization, plastification at the expanse of introducing fat components. It essentially widens a possibility of the technological use of defatted sour milk cheese and allows to elaborate the wide assortment of semi-products and ready products on its base.

At the same time it is determined that the exceeding of the rational milk decalcification level results in decreasing the sour milk cheese quality. Alongside with it the obtained results open prospects of using the decalcification process for receiving concentrated products of milk proteins with new functional-technological properties - dispersity, solubility, ability to emulsification and other ones.

\section{References}

[1] Bergamaschi, M., Cipolat-Gotet, C., Stocco, G., Valorz, C., Bazzoli, I., Sturaro, E. et. al. (2016). Cheesemaking in highland pastures: Milk technological properties, cream, cheese and ricotta yields, milk nutrients recovery, and products composition. Journal of Dairy Science, 99 (12), 9631-9646. doi: 10.3168/jds.2016-11199

[2] Loretc, O. G. (2014). Molochnaya produktivnost' i tekhnologicheskie svoistva moloka razlichnyh genotipov po kappa-kazeinu. Veterinariya Kubani, 2, 6-8.

[3] Castillo, M., Payne, F. A., Wang, T., Lucey, J. A. (2006). Effect of temperature and inoculum concentration on prediction of both gelation time and cutting time. Cottage cheese-type gels. International Dairy Journal, 16 (2), 147-152. doi: 10.1016/j.idairyj.2005.02.006

[4] Cassandro, M., Dalvit, C., Zanetti, E., De Marchi, M., Dal Zotto, R. (2007). Genetic aspects of milk coagulation properties in dairy cattle. Poljoprivreda, 13 (1), 30-34.

[5] Philippe, M., Legraet, Y.,Gaucheron, F. (2005). The effects of different cations on the physicochemical characteristics of casein micelles. Food Chemistry, 90 (4), 673-683. doi: 10.1016/j.foodchem.2004.06.001

[6] Faka, M., Lewis, M. J., Grandison, A. S., Deeth, H. (2009). The effect of free Ca2+ on the heat stability and other characteristics of low-heat skim milk powder. International Dairy Journal, 19 (6-7), 386-392. doi: 10.1016/j.idairyj.2008.12.006

[7] Udabage, P., McKinnon, I. R., Augustin, M. A. (2001). Effects of Mineral Salts and Calcium Chelating Agents on the Gelation of Renneted Skim Milk. Journal of Dairy Science, 84 (7), 1569-1575. doi: 10.3168/ jds.s0022-0302(01)74589-4

[8] Grinchenko, N. G., Tyutyukova, D. O., Pivovarov, P. P. (2017). Modifikatsiya struktury ta funktcionalno-tekhnologichnyh vlastivostei kazeinu: naukovi ta prikladni aspekty. Pishchevaya nauka i tekhnologiya, 11 (1), 57-68.

[9] Broyard, C., Gaucheron, F. (2015). Modifications of structures and functions of caseins: a scientific and technological challenge. Dairy Science \& Technology, 95 (6), 831-862. doi: 10.1007/s13594-015-0220-y

[10] Xu, Y., Liu, D., Yang, H., Zhang, J., Liu, X., Regenstein, J. M. et. al. (2016). Effect of calcium sequestration by ion-exchange treatment on the dissociation of casein micelles in model milk protein concentrates. Food Hydrocolloids, 60, 59-66. doi: 10.1016/j.foodhyd.2016.03.026

[11] Plotnikova, R., Grynchenko, N., Pyvovarov, P. (2016). Study of influence of technological factors on the sorption of ionized calcium from skimmed milk by sodium alginate. Eastern-European Journal of Enterprise Technologies, 5 (11 (83)), 32-39. doi: 10.15587/1729-4061.2016.81413

[12] Bobylev, D. O. (2016). Sravnitelnyi analiz metodov proizvodstva tvoroga. Konkurentosposobnost territorii: materialy XIX Vserosiiskoi ekonomicheskogo foruma molodyh uchenyh i studentov. Ekaterinburg: Izdatelstvo Uralskogo gosudarstvennogo ekonomicheskogo universiteta, Part 7, 152.

[13] Plotnikova, R., Grynchenko, N., Pyvovarov, P. (2016). The study of sorption of the milk ionized calcium by sodium alginate. EUREKA: Life Sciences, 4, 45-48. doi: 10.21303/2504-5695.2016.00191

[14] Nelson, B. K., Barbano, D. M. (2005). A Microfiltration Process to Maximize Removal of Serum Proteins from Skim Milk Before Cheese Making. Journal of Dairy Science, 88 (5), 1891-1900. doi: 10.3168/jds. s0022-0302(05)72865-4

[15] Doslidzhennia sensorne. Metodolohiya. Zahalni nastanovy. (ISO 6658:1985, IDT): DSTU ISO 6658:2005 [Chynnyi vid 2006-01-07] (2006). Kyiv: Derspozhyvstandart Ukrainy, 26. 